\title{
Os predicados da ordem: os usos sociais da justiça nas Minas Gerais 1780-1840 ${ }^{1}$
}

Ivan de Andrade Vellasco Universidade Federal de São João del Rei - UFSJ

\section{Resum O}

Através da análise da atividade do sistema dejustiça na comarca do Rio das M ortes, durante o período de construção do Estado imperial, este artigo busca elucidar seus usos esignificados entre os diferentes grupos sociais, salientando sua presença na resolução dos conflitos cotidianos e na negociação da ordem. Pretende-se discutir determinados aspectos da construção do Estado, associados ao processo progressivo de monopolização e controleda ordem social, sendo esta tomada como resultante da crescente capacidade do Estado em negociar seus parâmetros através do sistema jurídico.

Palavras-chave: Estado; Justiça; Sociedade.

\section{ABSTRACT}

Through an analysis of the justicesystem activity in the region of Rio das M ortes (M inas Gerais) throughout the Imperial State construction, we intend to clarify its uses and significations for the population, highlighting its presence in the resolution of everyday conflicts among the various social strata. A discussion is carried out on certain aspects of the building of the State related to the continuous process of social order monopolization and control, this being taken as a result of the State's growing capacity to negotiate its parameters through the juridical processing.

Keywords: State; Justice; Society.

\section{O TEMA DA JUSTIÇA NA HISTORIOGRAFIA}

Em boa parte da produção historiográfica, a formação do Estado nacional é descrita, grosso modo, como o desenrolar de uma paulatina imposição de uma ordem e dominação sobre o conjunto da sociedade, cujos setores, à exceção do dominante, seriam amorfos e incapazes de resistir ou negociar alternativas. As anál ises centradas no processo de construção e consolidação do Estado, tradicionalmente, têm se detido nos atores que atuaram a partir "de dentro", nos setores dominantes que ocupavam posições de poder econômico 
ou político e das relações entre eles, seus interesses, estratégias e alianças. A inexistência de uma "sociedade civil", de grupos sociais com capacidade de organização e pressão que se contrapusessem aos interesses das elites dominantes, somada à real idade do sistema escravista e seu caráter profundamente excludente, teria feito que o teatro político do Império se realizasse praticamente à margem, e por cima, da mai or parte da população, formada por escravos, libertos e homens livres pobres. A grande maioria desses setores não se teria feito presente na arena política, até mesmo pela absoluta inexistência de canais institucionais capazes de absorver, em um modelo minimamente representativo, seus anseios e demandas. Assim, sua irrupção no cenário político, quando e onde tenha ocorrido, teria sido pontual e não dirigida ao Estado, mas a situações de dominação cuja visibilidade era imediata, ainda que produzidas ou sustentadas pela atuação da máquina estatal. Torna-se, portanto, pouco relevante perguntar-se sobre o que significava o Estado para a maioria da população cujos papéis no drama que se desenvolve eram inteiramente secundários, oscilando entre a acomodação e a resistência espasmódica em movimentos erráticos.

Entretanto, é forçoso reconhecer que o poder do Estado que se afirmava não podia prescindir, no controle da ordem e na administração dos conflitos sociais, de espaços e margens de negociação. Era nesses espaços que se definiam os limites da obediência e da revolta, que se estabelecia "uma contínua sondagem entre governantes e súditos, a fim de descobrir o que eles podem efetuar impunemente".'2 As situações de domínio necessitavam manter uma base de legitimidade e seus ratios de poder articulados a al guma forma de reciprocidade e negociação com a massa de excluídos das arenas decisórias do Estado, fossem eles os homens livres pobres, os mestiços e negros libertos, ou os setores médios emergentes, que apresentavam padrões mais sistemáticos de busca de participação e intervenção na esfera política. N egociação essa que incluía, como vários trabalhos recentes o têm demonstrado de modo inequívoco, a imensa massa de escravos. ${ }^{3}$ O u seja, a manutenção da ordem e do controle social, aspectos centrais na viabilização das formas de dominação, não se assentavam exclusivamente, nem o poderiam, no recurso à violência e às forças de repressão, até porque são temas constantes nos documentos da época - correspondência de juízes e magistrados, relatórios de ministros e presidentes de províncias sobre a segurança pública - as queixas sobre a ineficiência das forças de repressão e a apresentação, sistemática, de um quadro nada promissor a respeito do aparelhamento das forças públicas.

Uma imagem instrumental do poder judiciário e suas relações com a po- 
pulação faz parecer que esta apenas assistia passivamente aos exercícios de poder de uma burocracia que, em última instância, era somente uma fachada legal para o domínio e controle estatal em consonância com os interesses políticos e econômicos dos potentados locais. Esta visão historiográfica tem sido consistentemente questionada a partir dos trabalhos que, ao se deterem sobre os processos criminais e fontes judiciárias, revelam que homens e muIheres pobres, mestiços e escravos, aí aparecem não apenas como réus, mas como vítimas e queixantes que demandam a ação e intervenção da justiça. O bviamente, não se trata de inverter o quadro em prol de uma visão que lhe seja diametral mente oposta. Parece nítido que em uma estrutura social perversa e altamente desigual, al icerçada num sistema escravocrata, a justiça assumia, em vários momentos de seu exercício, uma função diretamente relacionada às formas de dominação. Entretanto ela o fazia em consonância e atenção a um modelo que constitui uma racionalidade própria e que, por sua especificidade, como uma burocracia voltada para o implemento de normas e regras impessoais, se constitui num campo permanentemente aberto ao questionamento eà expressão dos conflitos. ${ }^{4}$

É lugar comum em nossa historiografia a caracterização da justiça no I mpério como ineficiente, inoperante e, sobretudo, inacessível aos que não perfilassem na estreita faixa social dos homens de posses e recursos. A administração da justiça, por suas precariedades e vícios de origem, uma estrutura arcaica e um arcabouço legal ultrapassado e confuso herdados da metrópole quando da implementação do Estado fiscalista, tem sido freqüentemente caracterizada como representando um dos aspectos mais cristalinos e reveladores da ineficácia e debilidade do poder público, incapaz de fazer frente aos poderes privados e suas formas de justiça direta. Em Caio Prado Júnior encontra-se uma exposição desse quadro herdado da administração colonial: "Justiça cara, morosa e complicada; inacessível mesmo à grande maioria da população". O autor conclui afirmando que "se o banditismo e o crime permanente não assolaram a colônia excessivamente, isto se deveu muito mais à índole da população, e não às providências de uma administração inexistente na maior parte do território da colônia". ${ }^{5}$

Vários autores que analisaram as imbricações e vicissitudes dos arranjos que marcaram a ação dos poderes de Estado, em seu processo de centralização, frente às diversas formas de manifestação dos poderes privados e locais, realizaram um diagnóstico semelhante da ação da justiça e seus impedimentos. De modo geral, a ordem legal se apresentava como uma ficção que, quando muito, poderia se prestar a ser apropriada e instrumentalizada pelos po- 
derosos como uma exten são de seus exercícios de dominação, fizessem eles parte da burocracia de Estado ou fossem parte da plutocracia imperante em determinado território. De resto, a persistente incapacidade, ou mesmo impossibilidade, do Estado, face aos arranjos e compromissos que supriam sua autoridade, em construir e efetivar uma arena burocrático-legal capaz de descolar-se das ingerências solapadoras dos poderes privados do patronato, tornou a justiça no transcorrer do Império algo virtual e rarefeito.

Para M anuela Carneiro da Cunha a contradição fundamental entre, de um lado, o discurso liberal de uma elite inserida no circuito do capitalismo mundial e, de outro, uma economia baseada no trabal ho escravo e nos laços de dominação pessoal, teria ocasionado a existência de uma separação irredutível entre o formal e o real, entre o direito positivo e o direito costumeiro, com suas distintas esferas de atuação. Ao direito costumeiro caberia reger as relações entre senhores e escravos, ambos colocados respectivamente acima e abaixo da lei; ao direito positivo, às leis e ao sistema jurídico, restaria o universo dos homens livres pobres. Resta a questão de se esses homens poderiam esperar da justiça a defesa de seus direitos em face da lei. A julgar pela "posição de classe" dos juízes e por sua "função política", seria pouco provável que a aplicação da justiça se fizesse com um mínimo de universalidade, tal como preconizado no direito positivo. ${ }^{6}$

Trabal hos como o de Fernando Uricoechea e de M aria Sylvia de CarvaIho Franco, que se inserem nessa perspectiva, embora não tenham o objetivo central de anali sar a justiça e seu funcionamento, na medida em que ambicionavam explicar processos mais amplos, apontam os mesmos problemas. Para Uricoechea, a possibilidade de implementação de “um padrão normativo" era permanentemente posta diante de constantes entraves acarretados pelo estado de indigência brancaleônica do aparato administrativo, bem como obstruída "pelo imenso poder que desfrutavam os proprietários de terras locais e suas clientelas patriarcais".7 A precariedade de uma ordem institucional era dada pelas condições do terreno no qual ela buscava se alicerçar, dominado pela ingerência das forças privadas que o Estado necessitava "cooptar patrimonialmente" a fim de poder exercer o monopólio legítimo da coerção.

Em M aria Sylvia Franco, entretanto, a abordagem do problema é mais específica, uma vez que as próprias fontes que utiliza - processos criminais - permitiram à autora deter-se sobre o funcionamento da justiça no município de Guaratinguetá. A ênfase nos laços de dependência e submissão do homem livre pobre e sua total incapacidade para a ação autônoma, somadas às considerações sobre a indiferenciação entre o espaço público e o poder pri- 
vado, levam-na a concluir, categoricamente, sobre a impossibilidade do recurso à justiça por parte daqueles que não pertencessem à camada dominante. ${ }^{8}$ Veja-se, na mesma direção, Sérgio Adorno, por exemplo, afirmar que "o exercício da justiça, como algo público, extravasava os limites da consciência do homem comum" e ainda que "os fazendeiros mantinham controle quase absoluto sobre o veredicto do júri e sobre as decisões judiciárias". ${ }^{9} \mathrm{E}$, mais recentemente, o livro no qual o autor, baseando-se diretamente nas fontes de M aria Sylvia Franco, afirma taxativamente que "se a presença dos homens livres e pobres era predominante como acusados, o mesmo não acontecia quando eram vítimas de crime, pois negou-se a eles até mesmo o direito de recorrer à justiça"." ${ }^{10}$

O trabalho de Patricia Ann Aufderheide, ${ }^{11}$ em meados da década de 1970, avançou questões importantes sobre o tema da justiça e seu papel na intermediação das relações sociais e administração dos conflitos entre iguais. Para os objetivos da discussão que se pretende desenvolver, é importante ressaltar, em primeiro lugar, o fato de que, ao contrário das interpretações até então predominantes, a autora considera a justiça como uma instância fundamental de mediação dos conflitos que surgiam permanentemente entre os que partilhavam um "acordo básico" sobre as normas. Esse papel fazia do sistema judiciário uma instância de reiteração das relações tradicionais, exatamente por essa capacidade de processamento das disputas que lhe permitiam reafirmar a ordem e seus pressupostos hierárquicos. Em segundo lugar, ela afirma que esse espaço público de mediação era, muito provavel mente, mais necessário àquela camada formada pelos homens livres sem propriedade (free but propertyless), pela precariedade de sua situação, por terem o que defender e pouco poder para tal, e por sua presença crescente na vida social, proporcionalmente aos demais grupos. Por último, salienta o processo de ampliação da justiça e padronização dos procedimentos legais, através das reformas judiciais, limitando o arbítrio do poder privado e tornando-se acessível "ao crescente número de homens livres que a usariam para arbitrar suas desavenças". ${ }^{12}$

A partir dos anos 80 começaram a surgir trabalhos, com inequívoco lastro empírico, cujas fontes eram exatamente processos criminais, ações de liberdade, livros de sentenças, enfim, a documentação produzida pelo sistema de justiça. Talvez um dos traços mais distintivos dessa produção seja, além do tratamento exaustivo da documentação, uma disposição menos apriorística na leitura das fontes e menos ancorada em pressupostos teóricos rigidamente definidos. A revisão historiográfica então realizada ampliou consideravel mente o escopo da discussão sobre o tema da justiça e seus usos. Centrada, sobre- 
tudo, no universo da escravidão, e aí, nas complexas relações entre senhores e escravos e nas estratégias usadas por estes na busca da liberdade, ou mesmo no questionamento dos poderes senhoriais, essa produção trouxe à cena o Estado e seu aparato judicial, como permanente mediador das tensas e ambíguas relações geradas no interior do sistema escravista.

Em Campos da violência a autora discute aspectos da montagem das estruturas de controle social na segunda metade do século XVIII, ressaltando as medidas que visavam à centralização eà padronização na aplicação das leis, com vistas à regulagem do poder senhorial em termos de parâmetros toleráveis. A discussão do castigo e suas aplicações são exemplificações do controle do Estado sobre os limites da justiça privada - trata-se aqui da mais restrita esfera privada, pois refere-se ao domínio dos escravos. Buscava-se cercear o poder privado do proprietário, através de punições e penalidades que o contivessem, sem, contudo, deixar que, aos olhos dos escravos, isso se definisse como uma brecha para o enfraquecimento do poder dos senhores e um espaço para o seu enfrentamento respaldado pelo poder da Coroa. Por fim, a "imagem cristalizada da fragilidade do poder público no interior da colônia" é questionada. 0 poder público não era fraco, muito menosinexistente, era reconhecido enquanto tal e utilizado, na medida da sua importância, no jogo social do poder; e tanto assim que era disputado pelos indivíduos ou grupos dominantes em luta. Nesse sentido, o recurso à instância jurídica implicava tornar público o particular, submetendo-o às regras e hierarquias; implicava buscar a mediação entre interesses heterogêneos, e não uma mera instrumentalização a serviço de interesses dados como unívocos. ${ }^{13}$

Sidney Chalhoub, em trabal ho em vários aspectos inovador sobre as últimas décadas da escravidão, ressal ta as diversas estratégias pelas quais os escravos buscavam obter sua liberdade, via justiça, e questionar os limites do sistema escravista e sua lógica. Suas ações judiciais afirmavam noções próprias sobre seus direitos e as formas 'toleráveis' do exercício da escravidão: 0 preço justo da alforria, a recusa à migração forçada, o direito à manutenção dos laços familiares, a denúncia de tratamento injusto e castigos excessivos por parte dos proprietários, entre outras queixas, faziam parte do leque de questões que os escravos apresentavam nas cortes, conseguindo aí "impor pelo menos em parte certos direitos adquiridos e consagrados pel o costume". E nas cortes e nos juízes, ao contrário de um aparato submisso aos interesses senhoriais, os escravos encontraram "uma arena decisiva na luta pelo fim da escravidão" em suas décadas finais. ${ }^{14}$

Hebe $M$ aria $M$ attos de Castro e Keila Grinberg ${ }^{15}$ deram contribuições sig- 
nificativas nessa direção. Suas obras avançam sobre o terreno contraditório das complexas relações entre o direito e o universo da escravidão durante 0 Império. Pela análise cuidadosa das ações de liberdade, entre outras fontes, as autoras apontam as imbricações entre o direito costumei ro e as leis positivas, ambas demonstrando que os "silêncios da lei" não impediram que as disputas entre escravos e senhores fossem encaminhadas através da justiça; tampouco que os escravos encontrassem aí as formas de apresentar suas reivindicações e utilizar-se do arcabouço jurídico consubstanciado nas ordenações filipinas, no direito romano, nas leis extraordinárias (inclusive as que versavam exclusivamente sobre a escravidão indígena), na defesa de seus direitos e legitimação de suas causas. E muitos ganharam e muitos perderam, mas plasmaram seus "significados da liberdade" também em uma arena cujos efeitos não foram definitivamente nulos. E as cortes não se limitaram ao papel de sustentáculos dos interesses senhoriais, nem os resultados das ações puderam ser antecipados ao seu desenrolar e aos seus rumos muitas vezes surpreendentes.

Por fim e retornando ao tema dos homens pobres livres frente à justiça, o estudo de Celeste Zenha realizou uma detalhada descrição e análise das práticas judiciárias em nível local, entre os anos de 1841 e 1890 no município de Capivari, no Rio de Janeiro. Partindo de um ponto de vista menos apriorístico, a autora conseguiu resultados mais aproximativos na compreensão e no desvendamento da trama e das motivações das ações que se desen rolam no sistema judiciário, realizando uma análise mais matizada tanto no que diz respeito à montagem e ao funcionamento do aparelho de justiça local, quanto no modo como foram processadas as "lutas entre os diversos poderes que forjaram a prática da justiça". ${ }^{16}$

Não deixa de ser curioso o fato de que a análise da justiça e de seus padrões de resposta às demandas sociais tenha sido reintroduzida e problematizada na discussão historiográfica a partir das pesquisas que se ocuparam dos seus usos e significados para os escravos que reivindicaram seus 'direitos' nos tribunais. Exatamente aqueles sobre os quais a lei silenciava e que, por definição, se viam excluídos do exercício dos direitos civis. Ao depararmos com a documentação produzida pelos tribunais de justiça, somos obrigados a reconhecer que, em alguma medida, os atores sociais que buscaram aí o reconhecimento e a efetivação de seus direitos perfizeram um leque mais amplo e significativo, socialmente, do que 0 até então suposto. Ali surgem homens e mulheres, representantes dos mais diversos estratos sociais, demandando a ação da justiça e buscando a efetivação de seus direitos formal mente garanti- 
dos. À medida que ampliamos as percepções sobre os usos sociais da justiça, torna-se possível redimensionar o debate dos espaços de cidadania e ativação dos direitos civis na sociedade que se desenha concomitantemente à emergência do Estado. Por mais limitadas e exíguas que possam ter sido as possibilidades de fazer valer o preceito da igualdade diante da lei, através do recurso à justiça foi experimentado e potencializado, pelos homens comuns, 0 exercício de direitos que, convenço-me cada vez mais, não estiveram ausentes nem foram de todo desprezíveis na nossa formação social. ${ }^{17}$

\section{OS USUÁRIOS DA JUSTIÇA}

No período que vai da segunda metade do século XVIII ao primeiro quartel do século XIX, a retração da atividade mineradora acentuara o processo de diversificação das atividades produtivas ea alternância, em termos do desenvolvimento econômico, entre as diversas regiões das M inas Gerais. ${ }^{18} \mathrm{~A}$ comarca do Rio das M ortes se projetara como a mais populosa e economicamente dinâmica ao final do período, abarcando os maiores entrepostos comerciais da província, São João del Rei e Barbacena. ${ }^{19}$ U ma estrutura produtiva diversificada e um complexo quadro de atividades ocupacionais serão características econômicas predominantes no cenário que analisamos.

0 al to grau de interdependência das diversas atividades econômicas que compunham o mosaico produtivo das M inas oitocentistas - interdependência essa gerada pela lógica dos "efeitos multiplicadores" de uma economia cujo centro dinâmico era a atividade exportadora - muito provavelmente seria responsável pela intensificação das redes de trocas sociais, da extensão e ampliação da base de sociabilidade necessária à estruturação dessas redes e, 0 mais importante aqui, das condições de previsibilidade da ordem, estabilidade de normas e condutas e confiabilidade em relação à expectativa das ações recíprocas. 0 que se argumenta é, em outras palavras, que ia longe a realidade de uma capitania colonial cuja atividade mineradora - eixo organizador da produção econômica e do mundo da vida - marcava em seus primórdios "a instabilidade social, a itinerância, o imediatismo, o caráter provisório assumido pelos empreendimentos". ${ }^{20}$

A crescente interligação comercial da região Centro-Sul e a afirmação da comarca do Rio das Mortes como centro produtor e abastecedor da Corte serão responsáveis por sua importância capital no processo de "interiorização da metrópole" e formação das bases do Estado nacional. ${ }^{21} \mathrm{~N}$ ão é inteiramente 
ocioso chamar a atenção para o fato de que as atividades comerciais, intensamente desenvolvidas no século XIX, somadas a uma produção diversificada e de intensa circulação pela província e fora dela, demandavam, por natureza, a existência de um mercado, cuja viabilidade se articulava estreitamente com a presença do fórum. ${ }^{22}$ Talvez seja o caso de sugerir que a imagem de anomia e desestruturação do mundo da vida dos homens e mulheres livres que não se localizavam nos extremos da estrutura social escravista seria inteiramente inadequada para descrever a realidade da época. A essa época a "estrutura movediça" da sociedade colonial e da economia mineradora, da qual nos fala Sérgio Buarque, já havia se sedimentado; os desclassificados já haviam sido absorvidos; a ordem já ganhara ares de permanência e duração. ${ }^{23}$

Q uanto à estrutura social é importante salientar ao menos dois aspectos. Em primeiro lugar, as possibilidades alargadas de independência econômica dos homens livres, asseguradas pela economia de subsistência. Como afirma D ouglas Libby, "não resta dúvida de que o recurso mais importante era 0 acesso à terra e a possi bilidade, ainda que parcial, de sobrevivência, através do cultivo e da criação para autoconsumo". ${ }^{4}$ Em segundo, 0 grau acentuado de generalização e pulverização da propriedade escrava fazendo que "o topo da pirâmide social, aquele constituído pelos proprietários de escravos [ fosse] surpreendentemente alargado [com] mais de dois terços dessa camada [possuindo] cinco escravos ou menos". ${ }^{25}$ O que, segundo o autor, se não permite afirmar a idéia de um escravismo democrático, uma vez que seguia existindo uma "enorme massa de unidades familiares que não participava da posse da mais básica forma de propriedade do regime escravista", ${ }^{26}$ reforça, entretanto, a idéia de que o alargamento ocorrido na base dos proprietários, com uma enorme quantidade de pequenos proprietários de escravos, teria garantido a base de sustentação política e social do regime escravista.

Some-se a isso o fato de o quadro populacional de M inas Gerais em 1821 indicar que, aproximadamente, 24 por cento da população negra era livre e, entre os mulatos, esse número subia para cerca de 90 por cento. ${ }^{27} \mathrm{E}$ não era desprezível a quantidade dos que, entre eles, conseguiram ascender socialmente através da posse de escravos. Tal fato levaria Evaristo da Veiga, em 1832, a argumentar que "posto que muitos mulatos e negros livres eram el es mesmos donos de escravos, deveriam compartilhar os interesses dos brancos para impedir que se difundisse o 'feroz haitianismo'". ${ }^{28}$ O u seja, estariam eles, tanto quanto os brancos proprietários, suficientemente comprometidos com o sistema escravista para não desejar a sua desestabilização, vale dizer, para não desejar a desestabilização da ordem reinante sobre as coisas e os homens. 
0 que o raciocínio de Evaristo da Veiga indica é a percepção de que a base social da ordem se ampliara, alargando a possibilidade de comprometimento de grupos, mais vastos do que os situados no topo da pirâmide social, com a sua manuten ção e defesa dos possíveis ataques da 'anarquia'. A incorporação ao mundo da ordem significava a absorção e entrada em um sistema de valores e regras garantidos, em última instância, pela existência do aparato jurídico e sua força coercitiva. A possibilidade de incorporação de indivíduos dos grupos sociais subalternos às fileiras dos estabelecidos, ou seja, daqueles que partilhavam alguma forma de acesso, ainda que reduzida, às oportunidades e aos bens que caracterizavam um horizonte de mobilidade na sociedade da época - o acesso à alforria, a posse de escravos e o uso da terra - estabelecia a base de aquiescência em relação às instituições que ordenavam o espaço social.

Através da análise da documentação judiciária da comarca do Rio das M ortes este trabal ho analisa as formas de interação entre a máquina judiciária e os diferentes grupos sociais ao longo do século XIX. A hipótese trabaIhada é a de que o judiciário ter-se-ia constituído em um lócus privilegiado do processo de negociação da ordem e afirmação do poder público como um espaço de mediação das relações sociais. Tratou-se de analisar o funcionamento da justiça e o seu significado social, no que diz respeito às alterações nas relações entre Estado e sociedade, à produção de representações sociais da justiça pública e seus espaços de ação, enfim, ao modo pelo qual a população estabelece as relações com o poder, naquele que é um campo de atuação decisivo do seu exercício.

Valendo-me dos livros de querela, rol dos culpados e processos criminais refaço al gumas trajetórias e componho al gumas histórias que buscam reconstruir a faina cotidiana da justiça e sua presença na administração dos conflitos diários. Artesãos, oficiais mecânicos, pequenos comerciantes, homens e mulheres pobres e escravos surgem nas páginas dos processos e dos autos não apenas como objetos inertes da ação de controle social e imposição da ordem, mas, e de modo surpreendentemente freqüente, como demandantes da lei e da ordem, naquilo em que elas podiam significar um instrumento para a obtenção de direitos e garantias consubstanciados nos códigos legais. A imagem resultante dessa reconstrução fica longe das visões prevalecentes a respeito da dinâmica que se estabelecia entre a sociedade e o poder judicial. Q uantificados, os demandantes da justiça surgem de diferentes posições na estrutura social, definindo um quadro que indica presença e legiti mação crescente de uma burocracia judiciária na administração dos homens e das coisas. Escra- 
vos elivres, homens e mulheres, pobres, ou das camadas intermediárias, compostas por pequenos artesãos, lavradores e comerciantes, e mesmo as elites locais - que supostamente estariam acima da lei — , todos esses, em maior ou menor grau, recorriam à justiça para solução de seus conflitos, e, de alguma forma, demandaram um espaço de ordem e previsibilidade para viver e trabalhar. E mais do que isso, enxergaram no recurso à justiça e na ativação das letras da lei uma forma de participar da ordem.

A análise dos livros de querela é bastante reveladora acerca de quem são e o que buscam os demandantes da justiça. Até a promulgação do Código do Processo Criminal havia duas formas de ação da justiça: as devassas e as querelas. As primeiras eram os atos jurídicos que partiam do próprio poder judiciário, podendo ocorrer numa época determinada do ano, as chamadas devassas ordinárias; as segundas consistiam em um "auto cível ou criminal iniciado por denúncia ou queixa feita por uma das partes; dizia-se perfeita aquela que envolvia, além da denúncia, juramento, indicação de três testemunhas e pagamento de fiança por perdas e danos, se o caso não pertencesse ao acusador". ${ }^{29}$ Os livros de querela encontrados, oito no total, cobrem um período que se estende de 1779 a 1833, quando com o novo código a forma é suprimida. Aí ficaram registradas as queixas levadas à justiça, as razões apresentadas pelos querelantes, acompanhadas muitas das vezes pelos depoimentos das testemunhas, e os exames de corpo de delito.

A Tabela 1 nos dá uma visão de conjunto dos motivos apresentados. Em função do que pretendo ressaltar, procurei manter ao máximo o registro da queixa tal como aparece no documento, agregando apenas aqueles cuja semel hança e pequenas variações tornaram possível agrupar sem interferir na amostra.

Tabela 1

Queixas nos livros de querela - 1779-1832

\begin{tabular}{lc}
\hline \multicolumn{1}{c}{ Queixa } & Total \\
\hline Abuso da filha & 1 \\
\hline Adultério & 5 \\
\hline Bofetada no rosto & 2 \\
\hline Bulra e enliciação & 1 \\
\hline Cárcere privado & 3 \\
\hline
\end{tabular}




\begin{tabular}{lc}
\hline Danos materiais & 16 \\
\hline Defloramento da filha & 1 \\
\hline Desonra à filha & 1 \\
\hline Estupro & 1 \\
\hline Falsificação de bilhete e furto & 1 \\
\hline Falsificação de crédito e carta para conseguir dinheiro emprestado & 1 \\
\hline Ferimentos em cavalo & 1 \\
\hline Ferimentos em gados & 1 \\
\hline Ferimentos, porretadas, açoites, espancamentos & 120 \\
\hline Furto & 61 \\
\hline Homicídio & 4 \\
\hline Indução de escravos & 4 \\
\hline Indução, sedução, fuga e prostituição com a mulher do querelante & 1 \\
\hline Invasão da casa & 1 \\
\hline Licitação eiliciação & 1 \\
\hline Matança de gados e tentativa de homicídio & 1 \\
\hline M atança de porcos & 1 \\
\hline M atança eferimentos de porcos & 1 \\
\hline M atou o porco do querelante e vendeu a carne & 1 \\
\hline M atou uma vaca do querelante & 1 \\
\hline Negociou o escravo do querelante & 1 \\
\hline Ocultamento de escrava & 1 \\
\hline Ofensas & 1 \\
\hline Rapto da filha & 1 \\
\hline Roubo, sedução, trai ção e calúnia & 1 \\
\hline Sedição & 1 \\
\hline Sedução & 1 \\
\hline
\end{tabular}




\begin{tabular}{lc}
\hline Tentativa de homicídio & 4 \\
\hline Uso ilegal de armas proibidas & 2 \\
\hline Venda ilegal de casa & 1 \\
\hline Venda ilegal de escravos & 1 \\
\hline Venda ilegal de terras & 1 \\
\hline Vendas de um cetro & 1 \\
\hline Total Global: & 251
\end{tabular}

Fonte: Livros de querela - AM RSJDR.

A maior parte das queixas contrapunha personagens do mesmo universo social, constituído por artesãos, ferreiros, roceiros, pardos, crioulos e brancos. Entre estes últimos, principalmente, figuravam também pessoas de posses, negociantes, padres, capitães e alferes, tanto como querelantes quanto como querelados. Casos como o de Dona Ana Bernardina de Castilho, que denunciou o assassinato de seu marido ocorrido na fazenda de seu pai, com um tiro de espingarda dado pelo escravo de seu pai José Benguela, "que serviu de sua pagem". ${ }^{30} \mathrm{O}$ u do alferes Bento Leite de Faria, "negociante de escravos negros novos ... senhor e possuidor de um sítio", que se queixa das agressões feitas a um de seus escravos. ${ }^{31}$ Embora sejam poucos os casos em que as ocupações de ambas, ou mesmo de uma das partes, tenham sido registradas nos livros de querela, o que não permite uma verificação mais apurada nesse sentido, a menção da cor torna possível uma quantificação mais representativa. $\mathrm{O}$ quadro resultante, até onde a cor pode ser tomada como indicativo das hierarquias sociais, dá mostras da diversidade tanto entre aqueles que se queixavam à justiça quanto daqueles que seriam os ofensores.

\section{Tabela 2}

Cor dos Querelantes - livros de querela 1779 -1832

\begin{tabular}{lc}
\hline Cor & Total \\
\hline Branco & 60 \\
\hline Cabra & 1 \\
\hline "Crioulo" & 8 \\
\hline
\end{tabular}




\begin{tabular}{lr} 
Pardo & 43 \\
\hline Preto & 15 \\
\hline Total: & 127 \\
\hline
\end{tabular}

Fonte: Livros de querela, AM RSJDR.

Tabela 3

Cor dos Querelados - livros de querela 1779-1832

\begin{tabular}{lr}
\hline Cor & Total \\
\hline "Bastardo" & 1 \\
\hline Branco & 54 \\
\hline Caboclo & 2 \\
\hline Cabra & 10 \\
\hline "Crioulo" & 23 \\
\hline Mestiço & 2 \\
\hline Pardo & 55 \\
\hline Preto & 4 \\
\hline Total: & 151 \\
\hline
\end{tabular}

Fonte: Livros de querela, AM RSJDR.

Na Tabela 2, computado o total das querelas em que a cor do querelante é designada, a presença de pretos, crioulos, cabras e pardos, somando mais de 50 por cento do total, é certamente um indicativo da extração social de grande parte daqueles que procuravam a justiça. A leitura mais detida desses registros reforça esses dados e ainda indica que, entre os declarados brancos, boa parte é constituída por homens e mulheres que pouco se diferenciam da condição social que prevalece no restante da amostra. Na Tabela 3 a amostra apresenta maior diversificação, com o surgimento de mestiços, bastardos e caboclos, designações que qual ificavam os descendentes indígenas, e um aumento da presença de pardos, crioulos e cabras. Somados, os não brancos compõem aproximadamente dois terços do total. A razão disso é o fato de que pardos, crioulos e cabras apresentavam queixas, na maioria dos casos, 
contra seus iguais em cor, sendo suas queixas contra brancos em número mais reduzido; por sua vez, os brancos, embora concentrassem suas queixas sobre outros brancos, as davam também de pardos e dos demais. Isso reforça a idéia de que as disputas se estabel eciam fundamentalmente entre os membros do mesmo grupo social, que competiam pel os mesmos recursos materiais e simbólicos, embora al gumas fronteiras fossem mais borradas, sobretudo as que separavam brancos e pardos; é entre estes que se apresenta o maior número de conflitos que extravasam as fronteiras da cor. Além disso, esses dados parecem indicar que, ainda que as condições econômicas os aproximassem - e por isso mesmo - , a cor permanecia funcionando como um critério de hierarquização social. A Tabela 4 apresenta uma visualização mais clara do que afirmo.

Tabela 4

Cor dos querelados e querelantes - livros de querela 1179-1832

\section{Querelantes}

\begin{tabular}{lccccccc}
\hline Querelados & Branco & Cabra & Crioulo & Pardo & Preto & Não consta & Total \\
\hline “Bastardo" & & & & & & 1 & 1 \\
\hline Branco & 21 & 1 & 1 & 7 & 2 & 22 & 54 \\
\hline Caboclo & & & & 1 & & 1 & 2 \\
\hline Cabra & 1 & & & 2 & 1 & 6 & 10 \\
\hline “Crioulo" & 3 & & 3 & 4 & 6 & 7 & 23 \\
\hline M estiço & & & & 1 & & 1 & 2 \\
\hline Pardo & 13 & & 2 & 15 & 4 & 21 & 55 \\
\hline Preto & & & & & 2 & 2 & 4 \\
\hline Não consta & 22 & & 2 & 13 & & 63 & 100 \\
\hline Total: & 60 & 1 & 8 & 43 & 15 & 124 & 251 \\
\hline
\end{tabular}

Fonte: Livros de querela, AM RSJDR.

Um outro dado acerca daqueles que procuravam os serviços judiciais é surpreendente e revelador. Do total de 251 lançamento nos livros de querela, 216 indicam o local de moradia do querelante; destes, 76 (35,2\%) são registrados como moradores "nesta vila", São João; sete (3,2\%) aparecem como 
moradores dos subúrbios da vila, arraiais ou paragens que podiam distar entre uma e duas léguas da vila; os demais 133 (61,6\%) eram moradores provenientes de aplicações, arraiais e vilas espalhados pelo vasto território da comarca do Rio das M ortes, tais como Lavras, Garambéu, Tamanduá, Três Pontas e Baependi, cuja distância da sede da vila de São J oão era significativa, algo em torno de quinze a vinte léguas, ou ainda mais. Ou seja, a maioria daqueles que se dirigiam à justiça, homens e mulheres o mais das vezes de nenhuma ou modestas posses, atravessava grandes distâncias, nas péssimas condições das estradas de então, na expectativa de fazer suas queixas serem ouvidas e ganharem curso nos trâmites jurídicos, em busca de resultados que talvez correspondessem às suas esperanças.

0 conjunto dos dados analisados parece indicar que, em primeiro lugar, ao contrário do que supõem al guns autores, a clientela do sistema de justiça que se vai desenvolvendo durante o século XIX apresentava uma diversidade social muito mais ampla, abrindo um leque que incorporava as demandas das diferentes classes e grupos étnicos que compunham a rede social. Em segundo lugar, as expectativas sociais em torno da justiça se manifestavam em toda a sociedadee, de modo acentuado, entre aquel es que não detinham poder pessoal ou posição para fazer justiça por seus próprios meios. Por último, era exatamente no horizonte de visão dos homens e mulheres sem posses que o ritual da justiça parecia ganhar contornos mais nítidos e carregados de significados. Razões para tal podem ser encontradas na leitura das querelas e processos.

José Antônio do Nascimento, homem pardo e "senhor e possuidor de uma vaca cor de rato", acusou Domingos da Silva Reis, "que assim se chamava em tempo de cativo e agora depois de forro se trata com o nome de Domingos osé de Souza", de têla roubado e vendido a carne no açougue deuma preta por nome Francisca Fernandes. ${ }^{32}$ Alexandre Gonçalves da Silva, "homem branco", dirigiu-se à casa do juiz ordinário, capitão J osé Lourenço, para "queixar denunciar e querelar de Bartolomeu Batista, crioulo forro casado" e seu vizinho, por ter este matado e desmanchado um porco que entrara em seu cercado e pertencia ao querelante. 0 querelado "vendeu partes das carnes e comeu o resto se lhe ficando por isso mesmo na pena de furto". ${ }^{33} \mathrm{M}$ anuel Gonçalves, "crioulo forro ... senhor e proprietário da preta por nome Joana, de nação Angola”, apresentou queixa de Leonor Teixeira da Conceição, "cabra ou crioula forra", pelos insultos e ferimentos feitos em sua escrava, "a qual estando quieta e pacífica sem dar causa alguma a ser ofendida, foi insultada e provocada ... por Leonor, [que] depois de lhe dar uns bofetões, Ihe fez com sua faca de ponta os ferimentos que constam do auto de exame". ${ }^{34}$ Ainda em 
uma briga entre dois homens, motivada pela disputa de "uns adobes", que resultou em ferimentos e acabou na justiça, uma testemunha al ega ter tentado dissuadir um deles alegando "que não parecia bem que sendo ele um homem pardo brigue com um negro publicamente". ${ }^{35}$

Esses relatos ti pificam os modos pelos quais as distinções vão sendo operadas em função dos lugares e papéis desempenhados frente à justiça por querelantes e querelados. Assim é que o pardo José Antônio do Nascimento se apresenta - ou é apresentado - como "senhor e possuidor de uma vaca" que Ihe teria sido roubada por um homem forro ao qual ele se refere pelo nome que possuía quando cativo, como a explicitar que a troca de nome não Ihe apagava a condição de origem ainda recente. A mesma condição de M anuel Gonçalves, também crioulo forro, a quem, no entanto, é dada a qualidade de "senhor e proprietário" de uma escrava, em sua queixa contra Leonor, também crioula forra. Como proprietários igualavam-se a Alexandre Gonçalves, branco edono de um porco, que teria sido roubado por seu vizinho Bartolomeu, crioulo forro. Através do registro público de suas posses, ambos eram reconhecidos como senhores de algo ou al guém, afastando-se ritual mente daqueles contra quem davam queixas, pela linha demarcatória fundamental de uma sociedade contraposta entre senhores e escravos, possuidores e possuídos. Algo ainda mais significativo pelo fato de serem situações como essas que traduziam as poucas possibilidades de diferenciação entre aquel es que competiam nos mesmos espaços sociais. Quanto aos forros, val e salientar que o ingresso na justiça como demandantes os igualava formalmente aos homens livres e os distanciava da sua condição anterior de escravo. É provável que todos eles tenham levado em conta a advertência contida no depoimento da testemunha, de não brigar com um negro publicamente, o que poria a perder a oportunidade que o momento Ihes apresentava, invertendo a assimetria da situação. ${ }^{36}$

A quantidade de casos de brigas, agressões e ferimentos que se originaram das tentativas de acerto de contas privadas, cobranças de pequenas dívidas e soluções de conflitos de posses indicam que não eram poucos os que recorriam a soluções privadas para problemas dessa natureza. Entretanto, acabavam por ver-se envolvidos no cerimonial jurídico como agressores e réus. Como no processo que envolveu Francisco Dias, sua mulher e sua sogra, "crioulos livres", presos e obrigados ao pagamento de fiança por terem espancado a forra Jacinta Prudenciana pelo sumiço de "uma camisa de caça e várias galinhas do poleiro". ${ }^{37}$ Também M aria M arcela, mulher parda e solteira, queixou-se da surra e das chicotadas que Ihe deram Gertrudes M artins, mulher cabra, seu marido Nicolau M oreira, a filha deste e sua irmã, mulher 
cabra, com seu marido, "homem de mistura da terra", além de uma escrava e outro homem. 0 motivo teriam sido "al gumas pequenas dívidas" que a querelada tinha com as outras envolvidas. ${ }^{38} \mathrm{Em}$ ambas as querelas os juízes condenaram os agressores. Provavelmente, casos como esse representassem um incentivo para que tais assuntos fossem entregues à deliberação da justiça.

Uma das razões que moviam aqueles que procuravam a justiça certamente residia em al gum cál culo razoável a respeito das possibilidades de atendimento de suas demandas. De um ponto de vista estritamentelógico, é pouco provável que tais cálculos não se fizessem presentes no ato dos que, cotidianamente e de maneira crescente, decidiam por submeter à apreciação e escrutínio das normas jurídicas suas desavenças, contendas e dramas particulares. A própria decisão de fazêlo é, por si só, indicativa de uma racionalidade que revela noções sobre a ordem coletiva e o papel das instituições em administrála, em oposição àqueles que, como vimos, movidos pelo impulso das paixões ou por outros cálculos, decidiam resolver por conta própria suas rixas e negócios. Ainda que a base de cálculo dos que recorriam ao arbítrio dos juízes fosse dada pela impossibilidade de enfrentamento do oponente por sua própria conta e risco, isso não seria um móvel suficiente para o recurso às vias legais. Restaria ainda, por exemplo, buscar socorrer-se junto aos que detinham prestígio e poder privado ou simplesmente resignar-se, o que é de supor que muitos tenham feito. 0 que quero dizer, frisando o que para alguns pode parecer óbvio, é que a demanda pela justiça na justiça revela uma escolha, entre outras possíveis e prováveis, que implica o acatamento prévio das regras e dos cerimoniais que a regem, tanto quanto al gum nível de crença na instituição e na sua eficácia resolutiva. Por eficácia deve-se entender a capacidade de processar e produzir resultados, que não podem ser aquilatados em termos de critérios formalmente definidos, mas, sobretudo, em relação às expectativas e motivações dos que pleiteavam sua ação. Em vários dos casos, como os aqui apresentados, essas expectativas pareciam girar menos em torno da imposição de penas e reparação, do que da possibilidade de tornar público um conflito pelo seu registro na arena jurídica, e sinalizar ao oponente uma disposição de enfrentá-lo legalmente elegitimar sua posição em relação ao outro. ${ }^{39}$

0 que tento exemplificar aqui é que, em grande parte, ainda que o acusado por algum delito ou conduta indevida pudesse ou conseguisse subtrairse às penas, seja dificultando o andamento da causa, obtendo a absolvição junto ao juiz ou frente ao júri, ou simplesmente fugindo - todas as três hipóteses eram freqüentes - , ainda assim seus acusadores poderiam sair moralmente vitoriosos da contenda. 0 acesso à justiça era, por si, um objetivo 
crescentemente almejado por aqueles que viviam ou tentavam viver em um acordo bási co com as regras sociais imperantes. A administração da justiça vinha, progressivamente, aumentando sua capacidade de responder a essas demandas e, nesse sentido, o juizado de paz visava propiciar o recurso à justiça a uma clientela mais ampla e, desse modo, solidificar o compromisso com a ordem sob controle dos poderes públicos. Ainda que fossem precários os instrumentos e os meios para impor a reta aplicação das penas previstas nas ordenações e, posteriormente, no código criminal, o fato de ser citado pela justiça por algum tipo de delito já implicaria transtornos e custos, inclusive materiais, capazes de dissuadir e refrear as ações futuras daqueles que se viam e viviam sob a esfera de ação e alcance dos juízes. Se é fato que a justiça implicava custos e despesas para aquel es que a ela recorriam, é certo que o mesmo era posto para aqueles que nela tinham de conduzir sua defesa, e, em caso de condenação, essas despesas seriam ampliadas para o total das custas do processo. Talvez isso não representasse grande coisa para os que nada tinham a perder, mas certamente não se dava o mesmo com os que necessitavam manter seu lugar social, seguir tocando seus negócios e desempenhando suas atividades e funções, garantias de sua inclusão no universo social. I sso incluía uma parte significativa dos atores presentes nas ações judiciais, incluindo réus, vítimas e testemunhas; artesãos, ofíciais mecânicos, lavradores, roceiros, militares de várias patentes e negociantes, enfim, eram representativos do amplo e diversificado espectro ocupacional do período. Para essa parcela da população, como afirma Patricia Aufderheide, a "preservação da lei e da ordem era a garantia do Estado à população estabelecida ... e a garantia para o Estado da continuidade da leal dade e dos rendimentos". ${ }^{40}$

A fórmula repetida nos autos de querelas, apenas com ligei ras variações "para sua (do querelado) emenda, exemplo dos outros e satisfação da república", talvez resuma as funções e os usos sociais da justiça numa sociedade como essa. Em primeiro lugar, é afirmada a necessidade de punição e contenção das condutas indesejáveis que constituíam o foco dos conflitos e precipitavam desafios à ordem, alicerçada em expectativas de comportamentos recíprocos; em segundo, é o caráter pedagógico da ação da justiça, que dissuadiria pela exemplaridade da punição e reconduziria o ritmo da vida aos trilhos desejáveis; e, por fim, a afirmação do Estado, do poder público expresso na forma 'república' que encerra, tanto o poder que a governa quanto o caráter de coisa pública da justiça.

Esse quadro, além de fornecer uma base compreensiva para o entendimento da ampliação e diversificação da demanda pela implementação da jus- 
tiça e, conseqüentemente, pelas expectativas de manutenção da ordem, torna possível explicar, em grande medida, a resposta do aparelho jurídico, mesmo que num plano limitado, em atendimento a essa demanda. Seja na sua progressiva expansão e reforma, assunto central na montagem da máquina, seja na capacidade operativa e em sua razoável eficácia no processamento e resolução das disputas jurídicas em atendimento ao que prescreviam as leis. Pelo menos, é o que faz supor o fato de que do total das querelas apresentadas à justiça constantes da Tabela 1, 169 nomes são encontrados no rol dos culpados, e seis outros na lista dos processos criminais, um total, portanto, de 70 por cento das queixas registradas, como mostra a Tabela 5. Considerando-se o reduzido número de processos que restaram do período, é possível ainda que esse número encontrado - seis processos - esteja sub-representado na amostra, já que não há homologia entre o conjunto destes e os lançamentos no rol dos culpados. I sso significa que a ampla maioria das querelas levadas à justiça resultou em conseqüências judiciais para aqueles que praticaram os delitos. O lançamento no rol já implicava pronúncia "à prisão e livramento", o que obrigava à obtenção da carta de seguro para permanecer em liberdade, coisa que muitos del es obtiveram, segundo as anotações sobre a "situação do réu" constantes no livro. Em vários dos registros constam, no mesmo campo, anotações como "dei mandado de prisão ao querelante no mesmo dia”, "preso", "foi remetido o translado da culpa para o Juízo de Fora do Rio", "fugiu", entre outras; todas elas indicações das medidas tomadas que, se não resultavam em prisão, implicavam custos impostos ao réu. D eve-se atentar, ainda, para o fato de o mandado de prisão ser entregue ao próprio querelante, coisa que certamente o colocava, além de moralmente vitorioso, em posse de um considerável instrumento de poder sobre o oponente, fonte de possíveis negociações e barganhas. 0 mandato de prisão era um documento legal a ser encaminhado às autoridades judiciais e policiais, do distrito ou freguesia, para que dessem cumprimento a ele.

Tabela 5

Querelas lançadas no rol dos culpados

\section{Querela}

Total

Adultério

Bofetada no rosto

Cárcere privado 


\begin{tabular}{lc}
\hline Danos materiais & 10 \\
\hline Defloramento da filha & 1 \\
\hline Facadas & 1 \\
\hline Falsificação de bilhete efurto & 1 \\
\hline Ferimentos em gados & 1 \\
\hline Ferimentos, porretadas, açoites,espancamentos & 76 \\
\hline Furto & 47 \\
\hline Homicídio & 3 \\
\hline Indução de escravos & 2 \\
\hline Indução, sedução, fuga e prostituição com a mulher do querelante & 1 \\
\hline Invasão da casa & 1 \\
\hline Licitação eiliciação & 1 \\
\hline Matança de gados e tentativa de homicídio & 1 \\
\hline Matança de porcos & 1 \\
\hline Matou uma vaca do querelante & 1 \\
\hline Negociou o escravo do querelante & 1 \\
\hline Ofensas & 1 \\
\hline Rapto da filha & 1 \\
\hline Roubo, sedução, traição e calúnia & 1 \\
\hline Sedição & 2 \\
\hline Sedução & 1 \\
\hline Tentativa de homicídio & 1 \\
\hline Uso ilegal de armas proibidas & 1 \\
\hline Venda ilegal de escravos & 1 \\
\hline Vendas de um cetro & 1 \\
\hline Total: & 1 \\
\hline
\end{tabular}

Fonte: Rol dos culpados, proc. criminais. AM RSJDR. 
Tal eficiência, obviamente considerada dentro das condições que analisei (nunca é demais repetir), alimentava as expectativas depositadas na ação da justiça, ampliando sua base de legitimidade, o que reforçava, por sua vez, a sua função social e firmava sua preeminência como arena de resolução dos conflitos e negociação da ordem. Fato que, certamente, melhorava sua capacidade de afirmar-se na disputa com outras fontes de recursos concorrentes, entre eles os poderes privados.

\section{A LUTA PELA JUSTIÇA NA JUSTIÇA}

Vimos como mulatos, pardos e negros libertos, tanto quanto homens brancos e livres, porém pobres, compareciam à justiça em busca de intermediação e arbitragem de suas disputas. Para a ampla maioria dos que compunham a base social da ordem, a justiça passava a representar um poder coativo capaz de intermediar e solucionar conflitos, aumentando as expectativas de ordem frente aos desafios competitivos permanentemente postos, tanto quanto um espaço de afirmação de valores e adesão à ordem como sinal de distinção social.

A historiografia vem já, de al gum tempo, desvendando as formas pelas quais os escravos, sobre quem as leis sempre se mantiveram no terreno da ambigüidade, perceberam na justiça as possi bilidades e brechas que tornavam possível superar a incapacidade jurídica que, do ponto de vista formal, os caracterizava. Para os libertos, que passavam a enfrentar obstáculos de toda natureza para sua plena incorporação à vida social, uma vez que medidas legislativas específicas sempre procuraram limitar seus espaços sociais, o recurso à justiça representava, seguramente, um ganho, propiciado pela nova condição; representava a probabilidade de, graças à intermediação e chancela do poder público, agregar status à condição existente e buscar uma integração à sociedade dos livres. Onde as oportunidades de inclusão e mobilidade se objetivavam no limite possível, tornar-se registrado para o poder público era um meio de reconhecimento de seus atributos como cidadão, de igualar-se sob padrões universal izantes.

Talvez, para aquele homem apresentado anteriormente, M anuel Gonçalves, "crioulo forro ... senhor e proprietário da preta por nome Joana", antes escravo, agora forro e proprietário de uma escrava, como para tantos outros da mesma condição, que deixaram suas queixas registradas, o acesso à justiça teria que ser conseqüência e desdobramento naturais do seu ingresso num 
mundo de livres e proprietários que, em ajuste com a ordem, deveriam lutar por suas posições, defendendo suas propriedades e seus direitos garantidos pela leis do Estado e do monarca. 0 que separava os estabelecidos dos que viviam à margem era o acordo básico sobre uma ordem plausível e uma conduta que buscasse demonstrar publicamente essa concordância; seja manifesta nas festas cívicas, nas disciplinadas manifestações religiosas das irmandades, em uma conduta pautada por princípios de acatamento das autoridades representativas do poder monárquico, e, finalmente, pelo recurso à justiça como o fórum de resolução de conflitos e implementação da lei e manutenção da ordem.

Eram esses mesmos personagens, forros, livres pobres, homens de condição modesta, roceiros, pequenos lavradores, artesãos, ven deiros e lavadeiras os que compareciam na justiça na qual idade de testemunhas. 0 papel dessas nos processos era extremamente relevante, uma vez que, mais do que as provas materiais - comumenteinexistentes - seus depoimentos é que constituíam a matéria da acusação. Segundo o Código do Processo Criminal, no artigo 134, bastavam para a formação do auto de corpo de delito, na inexistência de "vestígios que podem ser ocularmente examinados ... duas testemunhas, que deponham da existência do fato e suas circunstâncias". Para proceder à formação de culpa era suficiente que o juiz procedesse "à inquirição de duas até cinco testemunhas que tiverem notícia da existência do delito e de quem seja o criminoso". A lei da reforma de 1841 ampliaria esse número, nos casos de denúncia, para "cinco até oito testemunhas". ${ }^{41}$ Entretanto, pelo que se pode deduzir da leitura dos processos, esse número era freqüentemente superior, alcançando não raro o envolvimento de vinte, trinta ou mais testemunhas, o que indica um elevado grau de envolvimento e comprometimento com o processamento judiciário e seus resultados. Porém, o cerimonial da justiça Ihes possi bilitava espaços de afirmação de suas visões e construções próprias sobre a ordem e a justiça. Um dado interessante, nesse sentido, e que se evidencia nas narrativas dos processos e no modo como estes são montados, diz respeito ao papel atribuído às testemunhas, que se encarregam de revelar uma espécie de perfil sócio-comportamental do réu. Através dos seus depoimentos, via de regra vizinhos e iguais das partes envolvidas, vai-se construindo uma espécie de quadro de referências sobre quem era o réu, como costumava agir, enfim, qual a voz corrente a seu respeito. Os depoimentos iniciam-se pelas expressões "sabe por ver" e "sabe por ouvir dizer e ser público e notório", esta indicando, geralmente, uma avaliação pública sobre o réu e 0 que se diz sobre seu perfil moral e propensões, bem como seu envolvimento 
com o fato em pauta. Essa vox populi define, de certo modo, as características e o enquadramento do processo, o clima no qual se desenrolará. 0 papel das testemunhas se revestia de grande importância na resolução dos casos e no julgamento final, já que residia aí a fonte básica de elucidação do delito ocorrido. Perguntava-se sobre a conduta costumeira do réu, se este era turbulento e dado a violência, por exemplo; as testemunhas, vivendo nas mesmas condições do réu e da vítima, emitem suas opiniões sobre o que teria gerado a desordem, já que em muitos casos são os próprios vizinhos, depois testemunhas, que tomam a iniciativa de chamar o inspetor de quartei rão ou os guardas e efetuar a prisão. Assim eram elas, em última instância, que definiam a sorte e o destino dos réus.

Na denúncia feita por M aria Caetana ao juiz de paz de Santana do Jacaré, contra o escravo Quintiliano e José M achado, crioulo liberto, por terem invadido sua casa e a intimidado "com uma faca e um jogo de pistolas e ... à força usa[do] dela desonestamente", as cinco testemunhas do processo crime são unânimes em acusar o réu por duas razões: todas sabiam do fato "por ser público e notório" e "porque os dois são usados a fazer semelhantes aforçamentos". N enhuma delas presenciara o fato. ${ }^{42}$ Em outro processo, o procedimento final registrado realça a função das testemunhas: "por não ter o juiz mais a perguntar declarou ao réu que podia dizer e al egar o que tivesse em sua defesa, pois que a voz pública e as testemunhas o indicavam réu do delito, ao que nada respondeu". ${ }^{43}$

Com expressões como "segundo seu mau gênio e costumes", "por ser seu costume", "por ser violento e rixoso e turbulento", "por ter fama de val então", entre outras, as testemunhas vão afirmando seus valores e juízos morais a respeito dos réus, o que terminava por desenhar sua culpabilidade. O u sua inocência, quando através de frases como "respeitador das leis", "homem pacífico e temente a Deus", as testemunhas vão expressando suas simpatias.

Vejamos a história de M anuel M achado e Lauriano José de Souza, ambos pardos. Eles são acusados da morte de Antônio Dias de Carvalho, homem branco, ocorrida no Arraial do Córrego, curato da vila de São José, quando $M$ anuel M achado e Lauriano "vinham com suas famílias de uma novena que se fazia no Arraial do Córrego". Segundo uma das testemunhas, o caso se dera da seguinte maneira:

estando el e testemunha em sua casa aprontando-se para sair com sua família a ir assistir as novenas de Nossa senhora da Natividade ... ouviu ele testemunha uma gritaria assim como conheceu a voz de M anuel M achado [e gritos de] não 
matem o meu marido, e daí a mulher da testemunha abriu a porta e logo entrou $M$ anuel M achado com uma espada na mão ea outra mão muito ensangüentada dizendo ele que Ihe tinham cortado os dedos e daí saiu ele testemunha, fechou a sua porta elogo chegou a mulher de Lauriano de tal e perguntando ele testemunha que desordem foi esta, [ ela diz] eu ia cá atrás e vi dois vultos chegar [sic], um era o falecido e outro o não conhecia e dizendo o falecido a ele $M$ achado 'aqui é que se pagam elas' e o M achado e aquele Lauriano responderam 'também estou pronto' e meteram logo mãos aos ferros que traziam e aí houve a desordem e morte, e que sabe por ouvir dizer que o vulto que vinha com o falecido fora seu cunhado Patrício Gonçalves.

A tocaia armada por Antônio Dias, a vítima no processo e seu cunhado Patrício Gonçalves, contra Manuel M achado, tinha como motivo uma rixa anterior, que "principiara em um Domingo transato ... por causa de jogo onde houve descomposturas e brigas do falecido com o dito M achado". Antônio Dias e Patrício aguardavam M anuel na saída da novena, este vinha acompanhado de sua mulher e de seu amigo Lauriano, com mulher efilhos. A briga envolvendo os quatro resulta no ferimento de $M$ anuel e na morte de Antônio Dias. Na medida em que os depoimentos vão se somando começa a se desvendar uma história que, reconstruindo os antecedentes da briga, vai apontando os responsáveis pelo trági co acontecimento e o modo como as testemunhas os julgam, com sutis diferenças. Das 31 testemunhas arroladas na primeira parte do processo doze são brancas, duas cabras, quatro crioulas e treze pardas. Cabras, crioulos e pardos formam, portanto, uma ampla maioria. A exceção de duas testemunhas brancas, o restante é unânime em afirmar, por saber ou ouvir dizer, que a vítima, "que era homem mau por natureza", armara a tocaia "a esperar de propósito" com o objetivo de vingar-se de rixas anteriores havidas com M anuel, e aí começa a avultar-se o papel de Patrício Gonçalves, o parceiro e cunhado da vítima. Teria sido ele o principal responsável que "fomentara esse assassínio", tendo "instigado" e "incendiado" Antônio Dias a vingar-se "dos desaforos" que $M$ anuel Ihe fizera. Entre as doze testemunhas brancas seis se referem a Patrício como o instigador da tocaia e dos planos de vingança; já entre os treze pardos, dez denunciam o papel de lago desempenhado por Patrício. A diferença é relevante pelo fato de dois dos pardos e um crioulo acrescentarem o argumento que Patrício teria usado para convencer seu cunhado: a cor de M anuel. Um deles afirma que "ele fomentou dizendo que em um negro que passava a mão em um branco se dava pancadas"; outro afirmou que ele incitara o "falecido a ir fazer esse distúrbio" di- 
zendo que "um homem que nunca foi desfeitado não deveria ficar assim e muito mais de um negro que era o M achado"; por último, o crioulo forro Pedro da Silva depõe que

Patrício dissera ao falecido que era desaforo um negro dar em um branco e que se havia de desforrar, ao que respondia o falecido "isso já passou", [e] eleperto mais dizia 'tu então um homem de tanta fama há de ficar assim com um negro, tu não tens vergonha', e assim por este modo reduzira ao dito cunhado para a sua morte.

A penas uma testemunha branca se refere à cor alegando que Patrício teria dito "vós é [sic] um homem que tem fama de valentão, pega a arma que tem e vás disfarçar com aquele negro M anuel M achado". A diferença é que aqui a cor não éo elemento central e nem é acrescida da dramatização operada pela recriação dos enfáticos diálogos. M anuel, que no processo é descrito como pardo, aqui é dado como negro eé na qualidade de negros que as testemunhas, pardos, se colocam e definem sua solidariedade. Sentimento que se fazia presente nos demais pardos e crioulos que, não se referindo à cor, acusavam Patrício e sua conduta. De todo modo, os depoimentos acabam por definir um consenso que condena os "causadores da desordem", sobretudo Patrício, por instigar e, entre os pardos e negros, por seu racismo. U ma visão sobre o certo e o errado solidariza a todos e dentro dela, uma percepção mais específica da justiça, une pardos e negros. O s réus são absolvidos.

M as ainda um outro detalhe do processo revela certo domínio das estratégias possíveis no interior da justiça. Lauriano encontrava-se preso e M anuel $M$ achado fora encaminhado à Junta de Justiça na capital, O uro Preto. Uma vez lá, M anuel exime-se do crime antes confessado e, com a ajuda de testemunhas, transfere a culpa pela morte de Antônio Dias a Lauriano, que lhe teria dado o golpe fatal com uma foice. Inocentado pela junta de justiça, Manuel retorna e passa a assumir publicamente que fora el e o verdadeiro autor do golpe fatal, o que define o julgamento de Lauriano. No arrazoado de defesa apresentado pelo advogado de Lauriano ao júri, em São João del Rei, a estratégia é recontada:

Todos sabem que foi ele quem feriu e matou a Antônio Dias de Carvalho; todos admiram o seu valor, animo eintrépida resolução, mas como se procedia a devassa e se queria salvá-lo mudou-se a face das coisas: espíritos tíbios e fracos, perversos ou destros, ignorantes ou sábios o aconsel haram quenão fizessetal confissão 
... Este mesmo M anuel M achado apenas se viu livre por sentença da Junta de Justiça, tomou aquela linguagem de pureza e de justiça da qual usava antigamente, dando à inocência do réu [Lauriano] a homenagem que lhe era devida.

As testemunhas são novamente peças chaves no desfecho do processo, revelando um perfil de Lauriano como homem "de prudência e verdade em todos os seus tratos, sendo incapaz de faltar o respeito à lei e todas as autoridades", e que teria se visto envolvido na briga desarmado, já que se dirigira ao local "com sua mulher e três filhas por ser ele o que ia tirar a novena em razão de [ser] sacristão da Ermida". Além disso, afirmam ter sido mesmo M anuel que matara a vítima com sua espada, ou porque ele mesmo Ihes dissera ou porque viram a espada ensangüentada.

Assim, o júri responde os quesitos acusatórios "pela parte negativa" e o juiz conclui que "à vista da decisão do júri, com a qual me conformo, absolvo o réu da acusação intentada, o seu nome seja riscado do rol dos culpados, e se dê baixa na culpa". ${ }^{4}$

A exemplaridade dessa história se presta a resumir aspectos que surgem, embora não com essa riqueza ou de forma tão condensada, nos vários processo s examinados. A intervenção dos diversos atores no andamento e curso do processo, e os usos dos recursos disponíveis pela legislação denunciam a capacidade de atuar dentro do campo jurídico, em atenção às suas regras e procedimentos. Isso, certamente, indica a presença de uma atividade advocatícia expressiva e acessível a homens como Lauriano e M anuel M achado. ${ }^{45} \mathrm{Al}$ guns processos materializam batal has judiciais envolven do promotores, advogados e juízes, cujas reviravoltas, por sua vez, demonstram a dificuldade de antecipar os resultados das disputas travadas no interior da justiça. Como no caso da morte do escravo João Crioulo, cujo corpo é encontrado no Rio das M ortes. $O$ delegado de São J osé pronuncia dois homens como responsáveis pela sua morte que, segundo testemunhas, teria tido origem no espancamento sofrido pelo escravo, que se jogara no rio para escapar à agressão. 0 juiz municipal despronuncia os acusados, alegando tratar-se de um suicídio, e que o escravo fora pego roubando e tentara fugir. 0 promotor público recorre ao juiz de direito da comarca quanto à decisão tomada pelo juiz municipal e se inicia aí uma longa batalha jurídica entre as autoridades públicas. ${ }^{46} \mathrm{O}$ juiz de direito acata, ao final, o recurso do promotor e o caso é reaberto. Infelizmente a documentação não contém o desfecho da história.

Ainda um outro exemplo da utilização dos recursos legais pelos réus e seus advogados: o caso do escravo Francisco Antônio de Oliveira, o Porrada, acusa- 
do de matar Joaquim Antônio da Silva, por tê-lo surpreendido deitado com a filha de seu senhor, com a qual o escravo Francisco mantinha "relações ilícitas". Em que pese a situação Ihe ser desfavorável desde o início, em função dos depoimentos das testemunhas e do auto de corpo de delito, o processo se estenderá por dois anos, com várias trocas de curadores, recusa de jurados por parte do réu, direito assegurado pelo artigo 275 do Código do Processo, e ainda recurso ao Tribunal da Relação do Rio de Janeiro. Acrescente-se que o escravo Francisco foi, logo de início, entregue à justiça pela desistência de seu dono em encaminhar sua defesa. 0 réu foi condenado à pena de galés perpétuas. ${ }^{47}$

\section{CONCLUSÃO}

Inácio José queixa-se da embigada que Gregório teria dado em sua muIher; Manuel André queixa-se de um vizinho judeu que afirma que metade de seu sítio Ihe pertenceria; João Sampaio queixa-se de seu vizinho, o Sr. Tomás, que se apoderou de um leitão seu que, furando a cerca, havia invadido a horta do outro. Ao final, solicita ao juiz que mande "citar a Assembléi a provincial ... para mandar fazer cercados de espinhos em todas as hortas"; Francisco Antônio, natural de Portugal, queixa-se que o seu vizinho J osé da Silva se apoderou da cria de sua égua por ter o potro nascido "malhado como o seu cavalo"; Francisco alega que "os filhos pertencem às mães e a prova disto é que a minha escrava M aria tem um filho que é meu".

José é preso, a mando do juiz de paz, por Manuel João, roceiro pobre e soldado da Guarda, para ser enviado como recruta para lutar na província do Rio Grande. Não tendo onde passar a noite, preso à espera de ser levado à Corte, José é trancado em um quarto na casa do próprio M anuel João. À noite, a filha de $M$ anuel liberta o preso e com ele foge para se casarem, pois ambos se amavam havia tempos. Feito isso retornam e comunicam o fato consumado ao pai e todos se dirigem ao juiz de paz para comunicar o ocorrido ea impossibilidade de recrutar José, agora que ele é homem casado. 0 juiz aceita o fato, felicita os noivos e terminam todos dançando o "fado bem rasgadinho".

Como talvez o leitor já tenha se dado conta, todos esses relatos não são extraídos de fontes históricas, mas sim da peça 0 juiz de paz na roça, de Martins Pena, escrita provavelmente em torno do ano de 1833. A história de José constitui o enredo da peça e as demais são as queixas que ilustram o cotidiano de um juiz de paz na roça, ou seja, nas pequenas vilas efreguesias do país. Entretanto, todas elas expressam, com fidedignidade, o quadro que encontra- 
mos nos documentos e registros judiciais do período. A levar-se em conta os inegáveis tal entos de $\mathrm{M}$ artins Pena como cronista de sua época, atento ao universo social que o cercava, podemos pensar que a realidade, que encontramos nas fontes locais, correspondia a situações que vinham se generalizando à medida que a justiça se incorporava ao cotidiano das pessoas.

A análise da documentação judiciária parece confirmar essa impressão. Sobretudo quanto aos usos da justiça, pelas camadas populares e sua crescente presença nas cortes. N elas, se materializava a face da ordem capaz de atrair a participação e a anuência daqueles, para os quais as demais instituições do Estado eram abstrações distantes e excludentes. Isso se dava em função da capacidade do aparato de justiça de tornar-se, progressivamente, acessível às camadas subalternas, o que por sua vez representou uma pressão no sentido de fazêlo operar em níveis razoáveis de atendimento à lógica jurídica. I sso não significa que ela tenha prevalecido sobre as demais pressões que intervinham e agiam sobre a produção dos resultados. É claro que fatores extralegais e estranhos ao andamento jurídico poderiam intervir na produção de decisões - contrárias ou favoráveis - em se tratando de determinados grupos e pessoas cujas posições e ligações sociais fossem por diversos motivos privilegiadas. M as, uma vez ingressando na instância judiciária, o resultado não poderia ser inteiramente antecipado - ainda que calculado - uma vez que os níveis de embate se sobrepunham e podiam se anular, produzindo respostas as mais diversas nessa combinatória. A luta, uma vez na justiça, se tornava uma luta 'pela justiça' através da justiça. De qualquer modo, a justiça representava o campo possível de luta pela efetivação de direitos e, como afirma com precisão Sidney Chalhoub,

lutar dentro de um campo de possibilidades delimitado historicamente por condições específicas de exploração econômica e controle social é, afinal de contas, a experiência da maioria dos trabalhadores em qualquer tempo e sociedade. Raramente é possível, ou mesmo desejável, escapar para fora de um certo sistema de exploração e de uma determinada política de domínio. ${ }^{48}$

A justiça, certamente, ao mesmo tempo que representou um espaço de efetivação de certos aspectos da cidadania e apresentou-se como a face visível e tangível do Estado para os não dominantes, desempenhou papel importante na ampliação e consolidação da base social de sustentação do Estado I mperial, mais larga do que se supõe, quando se toma o conjunto da população como al heio ao que se passava na esfera pública; ela foi uma das engrenagens 
na montagem do campo de legitimação do poder imperial e, ao Império e aos seus homens de Estado, em suas ambições monopolizadoras, não passou desapercebida a sua função nem seu potencial de sedução para o campo da ordem. A face da justiça foi sedutora, na medida em que permitia incorporar os indivíduos às regras do jogo, oferecendo-Ihes possibilidades de usá-las como garantias de seus direitos.

0 interesse em manter a ordem afirmava-se como precondição para o exercício sistemático do poder. Para construir sua legitimidade, afirmar-se frente aos poderes privados e incorporar a população à sua esfera de ação, a justiça teria de ter algo mais a oferecer do que uma cena brechtiana na qual personagens estereoti pados representassem uma farsa. Para o conjunto da população, alguns mais, al guns menos, o acesso à justiça significava a possibilidade de ativação de direitos, e a percepção ea vivência dos mecanismos institucionais passavam a constituir um dos elementos de cálculo, sempre realizados em um quadro de incertezas e expectativas difusas, na busca de estabilidade de suas posições sociais e segurança e previsibilidade cotidianas. $H$ avia, portanto, níveis de confluência entre os interesses de ambas as partes na construção de uma ordem. I sso teria assegurado as bases de legitimação da lei e o acatamento dos preceitos reguladores das relações sociais, na medida em que a atuação dos juízes, promotores e advogados construiu as possibilidades de sua implementação e avalizou as expectativas sociais quanto à ordem legal.

As seduções da ordem se constituíam no fato de que essa ordem, razoavelmente alicerçada no poder judiciário, oferecia um campo de possibilidades, e, portanto, de previsi bilidade, de ativação de direitos fundamentais, através do manejo de regras que se foram positivando. $E$ qualquer regra é melhor do que jogar o destino ao arbítrio e ao capricho da sorte.

\section{NOTAS}

${ }^{1}$ Este trabalho é parte da tese de doutorado intitulada As seduções da ordem: violência, criminalidade e administração da justiça - M inas Gerais século XIX, desenvolvida no programa de doutoramento do Instituto Universitário de Pesquisas do Rio de Janeiro.

${ }^{2}$ M O ORE JR., B. Injustiça: as bases sociais da obediência e da revolta. São Paulo: Brasiliense, 1987, p.39.

${ }^{3}$ Para uma discussão e revisão da historiografia a respeito da escravidão no período ver, entre outros, REIS, J. J. \& SILVA, E. N egociação e conflito. São Paulo: Companhia das Le 
tras, 1989; LARA, S. H. Campos da violência. escravos e senhores na capitania do Rio de Janei ro (1750 -1808). São Paulo: Paz eTerra, 1988; CH ALH OU B, S. Visões da liberdade: uma história das últimas décadas da escravidão na Corte. São Paulo: Companhia das Letras, 1990; M ATTOS, H. M . As cores do silêncio: significados da liberdade no sudeste escravista - Brasil século XIX. Rio de Janeiro: Arquivo Nacional, 1995, e GRINBERG, K. Liberata - a lei da ambigüidade: as ações de liberdade na Corte de Apelação do Rio de Janeiro, sé culo XIX. Rio de Janeiro: Relume-Dumará, 1994.

4 "A mudança de espaço mental que está lógica e praticamente associada à mudança de espaço social garante o domínio da situação aos detentores da competência jurídica, os únicos capazes de adotar a postura que permite constituir esta situação em conformidade com a lei fundamental do campo. 0 campo jurídico reduz aqueles que, ao aceitarem entrar nele, renunciam tacitamente a gerir el es próprios o seu conflito ... ao estado de clientes dos profissionais; el constitui os interesses pré-jurídicos dos agentes em causas judiciais e transforma em capital a competência que garante o domínio dos meios e recursos jurídicos exigidos pela lógica do campo." BO U RDIEU, P. 0 poder simbólico. Lisboa: Difel, 1989, p.233. Para uma discussão da especificidade do direito e das leis na intermediação dos conflitos sociais ver THO M PSON , E. P. Senhores e caçadores: a origem da lei negra. Rio de Janeiro: Paz eTerra, 1987, e GEN OVESE, E. D. A terra prometida: o mundo que os escravos criaram. Rio de Janeiro: Paz e Terra, 1988.

${ }^{5}$ PRAD O JR., C. Formação do Brasil contemporâneo. São Paulo: Brasiliense/Publifolha, 2000, p.340.

${ }^{6}$ CUN H A, M . C. da. "Sobre os Silêncios da Lei: lei costumeira e positiva nas alforrias de escravos no Brasil do século XIX". In: Antropologia do Brasil: mito, história e etnicidade. São Paulo: Brasiliense, 1987.

7 URICOECHEA, F. 0 minotauro imperial: a burocratização do estado patrimonial brasileiro no século XIX. Rio de Janeiro: Difel, 1978, p.269.

${ }^{8}$ FRAN CO, M . S. de C. H omens livres na ordem escravocrata. São Paulo: Unesp, 1997.

${ }^{9}$ ADORNO, S. Os aprendizes do poder: o bacharelismo liberal na política brasileira. Rio de Janeiro: Paz eTerra, 1988, p.73-4.

${ }^{10} \mathrm{KOERNER}$, A. Judiciário e cidadania na constituição da república brasileira. São Paulo: Hucitec/USP, 1998, p.56.

${ }^{11}$ AUFDERHEIDE, P.A. Order and violence: social deviance and social control in Brazil, 1780-1840. Ph.D. Dissertation, University of M innesota, 1976.

${ }^{12}$ AUFDERHEIDE, P.A., op. cit., p.256.

${ }^{13}$ LARA, S. H., op. cit., cap. XIII.

${ }^{14}$ CHALHOUB, S., op., cit., p.173.

${ }^{15}$ M ATTOS, H. M ., op. cit., sobretudo a discussão que a autora desenvolve no capítulo IX; 
GRIM BERG, K., op. cit. Dessa mesma autora ver também "O fiador dos brasileiros": cidadania, escravidão e direito civil no tempo de Antônio Pereira Rebouças. Rio de Janeiro: Civilização Brasileira, 2003.

${ }^{16}$ ZEN H A, C. As práticas da justiça no cotidiano da pobreza: um estudo sobre o amor, o trabal ho ea riqueza através dos processos penais. Departamento de História, Niterói, UFF, 1984 (dissertação de mestrado), p.6.

${ }^{17}$ U ma discussão inteiramente pertinente nesse sentido é feita por Keila Grimberg, que sustenta a inadequação dos modelos formais de evolução da cidadania, centralmente T. H . $M$ arshall e seu roteiro evolutivo dos direitos civis, políticos e sociais, para a análise de situações históricas concretas que realizaram trajetos diferenciados na sua construção, afirmando que a "cidadania era um conceito em movimento no século XIX - se éque algum dia deixou de sê-lo - eportanto, não pode ser considerado resultado de uma expansão linear". GRIM BERG, K. 0 fiador dos brasileiros..., op. cit., p.23.

18 "A historiografia tradicional tende a caracterizar a economia mineira oitocentista como estando em constante crise de retração ou, pelo menos, como secularmente estagnada ... Sem dúvida, havia uma crise econômica que se foi prolongando até o segundo quartel do século. Não obstante, houve uma lenta e firme acomodação às crises através do crescimento do setor agrícola, marcada pelo tempero de certos ensaios industriais". LIBBY, D. Transformação e trabalho em uma economia escravista. M inas Gerais no século XIX. São Paulo: Brasiliense, 1988, p.96.

19 "A comarca de Vila Rica, nas quatro décadas seguintes ao censo de 1776, apresentou um declínio demográfico. Rio das M ortes, entretanto, no mesmo período quase triplicou sua população: de 82.781, em 1776, para 213.617, em 1821." M AXWELL, K. A devassa da devassa - A Inconfidência M ineira: Brasil e Portugal 1750-1808. Rio de Janeiro: Paz eTerra, 1978, p.110.

${ }^{20}$ SOUZA, L. de M e. Os desclassificados do ouro: a pobreza mineira no século XVIII. Rio de Janeiro: Graal, 1985, p.66.

${ }^{21}$ Ver a respeito DIAS, M . O. da S. "A interiorização da metrópole". In: M OTTA, C. G. (O rg.) 1822 Dimensões. São Paulo: Perspectiva, 1986. A obra decisiva sobre o tema éa deAlcir Lenharo. "O problema pode ser apresentado do seguinte modo: por que as estradas do Comércio e da Polícia, os projetos mais ambiciosos desta etapa administrativa, dirigiam-se para a comarca mineira do Rio das M ortes, e qual a importância estratégica para a Corte, uma vez seu principal núcleo abastecedor?". LEN H ARO, A. As tropas da moderação. São Paulo: Símbolo, 1979, p.63.

${ }^{22} \mathrm{~N}$ ão deixa de ser sugestivo observar o nome das duas estradas projetadas para ligar a região à Corte: estrada do comércio e estrada da polícia, ainda que esta última tenha sido batizada em função de suas obras terem sido postas a cargo da então Intendência de Polícia da Corte.

${ }^{23}$ "O s mapas de população são conclusivos: boa parte do contingente desclassificado havia 
se acomodado às realidades econômicas das Gerais pós-febre aurífera e se fizera parcela da vasta camada de pequenos produtores mineiros." LIBBY, D. Transformação e trabalho em uma economia escravista..., op. cit., p.92.

${ }^{24}$ LIBBY, D., op. cit., p.361. Seus dados apontam que, entre 1831 e 1840, a parcela de assalariados entre os homens livres era de apenas 7,8 por cento (p.91).

${ }^{25}$ LIBBY, D., op. cit., p. 82.

${ }^{26}$ LIBBY, D., op. cit., p. 97.

27 "Durantetodo o período colonial (edurante todo o Império também) M inas Gerais contou não só com o maior plantel mancípio, mas, ainda, com a maior população forra da colônia." PAIVA, E. F. Escravos e libertos nas M inas Gerais do século XVIII : estratégias de resistência através dos testamentos. São Paulo: Annablume, 1995, p.106.

${ }^{28}$ FLORY, Th. El Juez de Paz y el Jurado en el Brasil Imperial, 1808-1871. M éxico: Fondo de Cultura Económica, 1986, p.50.

${ }^{29}$ LARA, S. H. (O rg.) Ordenações Filipinas - Livro V. São Paulo: Companhia das Letras, 1999.

${ }^{30}$ Arquivo do Museu Regional de São João del Rei AM RSJDR, Livro 2, p.10, 1799.

${ }^{31}$ AM RSJ D R, Livro 9, p.30, 1830.

${ }^{32}$ AM RSJ DR, Livro 2, p.36, 1804.

${ }^{33}$ AM RSJ DR, Livro 2, p.64 e verso, 1808.

${ }^{34}$ AM RSJ DR, Livro 1, p.30 e verso, 1782.

${ }^{35}$ AM RSJDR, Livro 3, p.135, 1812.

${ }_{36}$ "Aqui está um outro meio de garantir a ordem social: permitir que quase todo mundo se sinta superior a alguém. As distinções matizadas de classificação social coibiam a ameaça que os homens livres talvez pudessem, de outra maneira, representar, e isso explica em parte por que se encorajava a alforria dos escravos: os negros livres inseriam-se facilmente num dos nichos sociais possíveis." GRAH AM , R. Clientelismo e política no Brasil no século XIX. Rio de Janeiro: UFRJ, 1997, p.49.

${ }^{37}$ AM RSJ D R, Proc. crime, cx. 4, 1834.

${ }^{38}$ AM RSJDR, Livro 4, p.59, 1821.

${ }^{39}$ Salientando a função da justiça no contexto europeu do início da era moderna, Weisser afirma que "o sistema de justiça, na forma como operava no nível local, era um perfeito método para espal har notícias através de toda a comunidade do lugarejo. Em vários aspectos esse era o mais significativo traço do procedimento pel o qual o queixoso poderia publicizar suas queixas e reaver algum senso da honra e prestígio perdidos". WEISSER, M . R. Crime and punishment in early modern Europe. New Jersey: Humanities Press, 1979, p.60. 
${ }^{40}$ AUFDERHEIDE, P. A., op. cit., p.72.

${ }^{41}$ Ver Código do Processo Criminal do Império do Brasil.

${ }^{42}$ AM RSJDR, Proc. crime, cx. 4, 1834.

${ }^{43}$ AM RSJ D R, Proc. crime, cx. 4, 1838.

${ }^{44}$ AM RSJDR, Proc. crime, cx. 3, 1831.

${ }^{45}$ Em sua estada em São João del Rei, John Luccock observa que "tanto os padres como os advogados parecem existir em grande número aqui, tal como se dá para outras localidades sujeitas à Coroa portuguesa, muito além mesmo do que o poderiam exigir os legítimos reclamos da Justiça e da Religião". LU CCOCK, J. Notas sobre o Rio de Janeiro e partes meridionais do Brasil. Belo Horizonte: Itatiaia, São Paulo: Edusp, 1975, p.305.

${ }^{46}$ AM RSJDR, Proc. Crime, cx. 6, 1845.

${ }^{47}$ AM RSJDR, Proc. Crime, cx.12, 1857.

${ }^{48}$ CH ALH OUB, Sidney. Visões da liberdade..., op. cit., p.252. 